\title{
Após Derrida: A AMIZADE FILOSÓFICA
}

\author{
After DerRida: The Philosophical Friendship
}

Evando Nascimento

Universidade Federal de Juiz de Fora

Juiz de Fora, Brasil

\begin{abstract}
Resumo
Abordagem das relaçóes entre o pensamento de Jaques Derrida e o de Walter Benjamin a partir da questão da tradução. Leitura do ensaio "Torres de Babel”, em que Derrida recorre ao famoso ensaio "A tarefa do tradutor", de Benjamin, para desconstruir uma teoria tradicional da tradução como transmissão do significado. Finalmente, interpretação da questão filosófica da amizade, a partir das relaçóes de Derrida com o pensamento de Benjamin, Heidegger e Gadamer, entre outros.
\end{abstract}

Palavras-chave: Derrida; Benjamin; tradução; amizade.

\section{Abstract}

Approach to the relationship between Jacques Derrida's and Walter Benjamin's thoughts on translation. Reading of the essay "Towers of Babel", in which Derrida, in order to deconstruct a traditional theory of translation as the convey of meaning, comments on Benjamin's famous essay "The Task of the Translator". Finally, an interpretation of the philosophical issue of friendship, having as a starting point Derrida's relation to the thoughts of Benjamin, Heidegger and Gadamer, among others.

Keywords: Derrida; Benjamin; translation; friendship.

\section{Résumé}

Approche des rapports entre la pensée de Jacques Derrida et celle de Walter Benjamin, ayant comme point de départ la question de la traduction. Lecture de l'essai « Des Tours de Babel » où Derrida a recours au célèbre essai «La tâche du traducteur », de Benjamin, pour déconstruire une théorie traditionnelle de la traduction en tant que transmission du signifié. Enfin, interprétation de la question philosophique de l'amitié, à partir des rapports de Derrida avec la pensée de Benjamin, Heidegger et Gadamer, entre autres.

Mots-clés: Derrida; Benjamin; traduction; amitié.

Gostaria que se lesse o título deste texto ${ }^{1}$ não no sentido simplesmente cronológico e menos ainda naquele de ultrapassagem. Após é, primeiro, o sinal do que se pôde ou do que se pode ainda fazer a partir de Jacques Derrida,

\footnotetext{
${ }^{1}$ A primeira versão desse texto corresponde à primeira parte de uma estadia pós-doutoral na Universidade Livre de Berlin, onde, bolsista dos governos brasileiro (Fapemig) e alemão (DAAD) em 2007, realizei pesquisas em torno das relaçóes entre Derrida e Benjamin. Uma leitura foi feita na "Journée Jacques Derrida" neste mesmo ano nas Facultés Saint-Louis de Bruxelas, graças ao convite de Michel Lisse. O ensaio foi originalmente publicado na coletânea de Danielle Cohen-Levinas e Ginette Michaud (Org.). Appels de Jacques Derrida. Paris: Hermann, 2014: 385-402.
} 
após sua partida e a partir de seu pensamento doador. Não para repetir o que ele disse, sempre melhor do que outros, mas para dizer e escrever o que ele nos teria ensinado a pensar, nós, seus leitores da França, do Brasil e de outros lugares; a pensar com nossos próprios recursos filosóficos, literários, existenciais, artísticos, em articulação com os dispositivos, estratégias e deslocamentos conceituais que ele colocou em prática em suas obras. Se o pensamento não é nem substância, nem função egológica (o Eu penso ou o Cogito cartesiano), nem mesmo atribuição ou tarefa de um só sujeito como no caso da reflexão filosófica, importa aqui destacar o estatuto do pensar como relação com o outro, seja o outro imediato, muito próximo, este ou aquele outro, seja o outro que está distante, estrangeiro, o outro que é completamente outro, irredutível a toda subjetividade ou instância ontológica. Isso implica a necessidade de pensar o próprio pensamento como amizade, vínculo da relação com o outro (como bem diz o phileîn grego), mas sem identidade, nem identificação narcisista ("amar o outro como a si mesmo"), nem projeção subjetiva, nem mesmo filiação genealógica.

Entre todas as relaçóes que Derrida estabeleceu e declarou ao longo de sua vida intelectual, há, porém, uma bastante especial que se encontra no centro de seu pensamento. Tal é a relação diante dos filósofos cujo trabalho é muito próximo do seu e, ao mesmo tempo, muito diferente, distanciado não somente do ponto de vista do estilo (no fundo, nenhum verdadeiro filósofo se assemelha a outro), como também do ponto de vista das estratégias. É, antes de tudo, a maneira singular com a qual cada filósofo trata os conceitos filosóficos que o distingue. A relação não estritamente conceitual de Derrida para com a conceitualidade filosófica, sem por isso fazer não-filosofia por incapacidade de filosofar, sua relação não estritamente filosófica para com a filosofia terá sido, então, a marca por excelência que ele deixou na tradição dita "metafísica", sem se reduzir a ela. Nomearei de maneira muito sintética seis de seus "amigos" filósofos, mais ou menos em sua sucessão temporal: Nietzsche, Benjamin, Heidegger, Levinas, Foucault e Deleuze.

Gostaria, então, a título de exemplo, mas isso será muito mais do que um simples exemplo, de falar da relação de Derrida com um desses filósofos, que não conheceu em vida o reconhecimento obtido por sua obra alguns anos após a sua morte. Trata-se de Walter Benjamin, pensador que deixou traços profundos em certos textos de Derrida, sobretudo naqueles que se desenvolvem em torno da tradução e do messianismo, dois temas maiores para as desconstruçóes (sempre consideradas no plural, mesmo se podemos, de maneira pontual, nos servir da palavra no singular). Todavia, diante da impossibilidade de abordar as relaçóes entre Derrida e Benjamin em sua totalidade, escolhi um de seus aspectos, que diz respeito justamente à tradução, 
para aí situar certos deslocamentos propostos por Derrida nos trabalhos de Benjamin, como caso exemplar (ao mesmo tempo em que póe em causa o valor mesmo do exemplo) das relaçóes de proximidade e de distanciamento de Derrida diante de certos filósofos.

A questão aqui seria uma inadequação, uma falta de exatidáo ou mesmo, talvez, uma certa "injustiça” das leituras que Derrida faz da obra de Benjamin. E como poderia ser diferente se a coisa mais difícil do mundo, à qual talvez todo intérprete deve renunciar desde o começo, é restituir em sua totalidade os sentidos de um texto ou de uma teoria tais quais eles foram concebidos por seu autor? Para haver leitura, já dizia a epígrafe de $A$ farmácia de Platão, é preciso pôr algo de seu, acrescentando alguma coisa ao tecido original do texto. E a partir do momento em que se acrescenta uma linha ao texto, não é mais o mesmo texto que se restitui após a leitura. Não é mais, sobretudo, o sentido único, completo, total, que, por hipótese, se encontrava escondido sob a última camada do texto dito original e que veio a ser restituído. A "Aufgabe" (palavra alemã que designa, por um lado, a tarefa, o dever, e por outro, o abandono ou a renúncia), a "Aufgabe" primeira do leitor consiste em compreender que a restituição ou o resgate completo do sentido é por definição impossível. É preciso renunciar a isso em todas as leituras, com o risco de não ler, de permanecer muito próximo do texto do ponto de vista filológico, sem lhe acrescentar o que quer que seja. Sem lê-lo realmente.

Renuncio, pois, no começo de meu discurso, a ser completamente justo com Derrida e com Benjamin. Não se trata, sobretudo, de tomar partido de um contra o outro, mesmo se a distância entre uma e outra assinatura é considerável, pois os efeitos de sentido e de contrassenso não são da mesma natureza nas obras de Derrida e de Benjamin. Não se deve, sobretudo, ceder à guerra ("And he war", veremos) dos sentidos, à verdade absoluta de um texto contra as suas derivaçóes e desvios (Umwege). É de outras "voltas" que falarei aqui e de outros volteios de frase, em uma língua que não é a minha.

Em seu célebre ensaio "Die Aufgabe des Übersetzers" (BENJAMIN, 1991: 7-21), traduzido para o francês como "La tâche du traducteur"2 (1923), Benjamin tenta fazer um contraponto a uma teoria tradicional da traduçáo, a qual pretenderia preservar um certo significado em uma nova estrutura de linguagem ou em uma nova língua. A teoria proposta por Benjamin tem

\footnotetext{
${ }^{2}$ Em português, esse ensaio de Benjamin foi traduzido por "A tarefa do tradutor" ou, como prefere Susana Kampff Lages, "A tarefa-renúncia do tradutor". A partir deste ponto, na tradução para o português desse texto benjaminiano citado por Evando Nascimento, optou-se pela edição brasileira. Neste caso, "A tarefa-renúncia do tradutor", traduçáo de Susana Kampff Lages, que constitui uma das quatro traduçôes propostas do ensaio "Die Aufgabe des Übersetzers", organizadas por Lucia Castello Branco no livro A tarefa do tradutor, de Walter Benjamin: quatro traduçôes para o português. Belo Horizonte: UFMG, 2008: 66-81. [N. do T.]
} 
como traço distintivo a supervalorização da forma em relação ao conteúdo, ao menos em se tratando de um simples conteúdo imediato. É o modo como se traduz que é decisivo para que a tarefa (die Aufgabe) do tradutor seja bemsucedida: "A tradução é uma forma [Übersetzung ist eine Form]. Para compreendê-la como tal, é preciso retornar ao original. Pois nele reside a lei dessa forma, enquanto encerrada em sua traduzibilidade" (BENJAMIN, 1991: 67).

O original de um texto não é capaz de efetuar, por si mesmo, o que somente o vasto trabalho do tradutor pode realizar. Na verdade, o que se deve considerar é a necessidade de pôr em evidência - em vez de simplesmente tornar o conteúdo disponível em uma nova língua - a relação que todas as línguas mantêm para com a língua dita original. Desse modo, a língua pura (die reine Sprache) se torna o meio primeiro e último de todo e qualquer ato de linguagem $^{3}$ que seja essencial. Todas as línguas guardam de uma certa maneira o traço de afinidade ou de parentesco (Verwandtschaft) dessa língua "verdadeira” (die wahre Sprache), e todas se orientam em direção a essa possibilidade geral de uma língua ou de uma linguagem (Sprache) que seja pura (reine):

Toda afinidade meta-histórica entre as línguas repousa sobre o fato de que, em cada uma delas, tomada como um todo, uma só e a mesma coisa é designada; algo que, no entanto, não pode ser alcançado por nenhuma delas, isoladamente, mas somente na totalidade de suas intençôes reciprocamente complementares: na pura língua. Pois enquanto todos os elementos isolados - as palavras, frases, nexos sintáticos - das línguas estrangeiras se excluem, essas línguas se complementam em suas intençôes mesmas [ergänzen diese Sprachen sich in ihren Intentionen selbst] (BENJAMIN, 2008: 72).

Uma língua, pois, pensada a priori como anterior à queda, ainda não contaminada por toda a impureza que a comunicação (die Mitteilung) implica. É por isso que Benjamin insiste no fato de que a tradução das obras poéticas (Dichtungen) nada tem a ver com a comunicação de conteúdos particulares. A tradução não pode apostar em uma função comunicativa, pois a obra literária ou poética não tem por finalidade a comunicação: "O que 'diz' uma obra poética? O que comunica? Muito pouco para quem a compreende. $\mathrm{O}$ que lhe é essencial não é a comunicação, não é o enunciado. E, no entanto, a tradução que pretendesse comunicar algo não poderia comunicar nada que não fosse comunicaçáo, portanto, algo inessencial [also Unwesentliches]" (BENJAMIN, 2008: 66).

Não esqueçamos que o texto “Die Aufgabe des Übersetzers” é o prefácio das traduçóes feitas por Benjamin dos Tableaux parisiens, de Charles Baudelaire.

\footnotetext{
${ }^{3}$ Embora Benjamin não utilize essa terminologia, o que seria totalmente anacrônico, interessa-nos aqui, antes de tudo, um certo contexto "pragmático", constituído por uma relação de forças que dá lugar a efeitos de significação. É o contexto histórico, epistemológico, político, linguístico etc., que está também implicado nessa questão da tradução, a qual, por sua vez, evoca múltiplos sentidos.
} 
Trata-se de todo um contexto de contato e, consequentemente, de tradução entre a França e a Alemanha, entre Paris e Berlim, que constitui o que está em jogo no ensaio. Benjamin fala a partir do lugar do tradutor de poesia, de uma poesia que se relaciona com a prosa, mas que náo deve se deixar contaminar pela impureza característica desta última. Cabe ao poeta, como ao tradutor, a mais alta tarefa, que consiste em abandonar tudo o que uma língua, por definição "prosaica" em seus usos cotidianos, ou seja, destinada a fins de comunicação, traz de inessencial, pois somente o essencial conta nessa infinita tarefa de tornar manifesta a relação profunda entre as línguas. O essencial é por definiçáo o intraduzível; traduzir no sentido tradicional implica a transferência de um certo conteúdo disposto em uma língua para uma outra. Conforme suas hipóteses, Benjamin afirma a tese segundo a qual o essencial não se traduz, não se deixa traduzir como ato de comunicação de um conteúdo-significado, mas se torna traduzivel como criação inventiva que "performa" a passagem do inessencial ao essencial, da língua (ou das línguas) de comunicação à língua pura, verdadeira, primeira. E o essencial repousa sobre a intencionalidade de cada língua particular em sua relação harmoniosa com as outras línguas. "Pois vale o princípio: se a tradução é uma forma, a traduzibilidade deve ser essencial a certas obras" (BENJAMIN, 2008: 67), de modo que Benjamin privilegia uma outra relação entre fidelidade e liberdade do tradutor diante do original. A verdadeira fidelidade somente pode ser, à sua maneira, "livre", e isso se faz por um equilíbrio entre literalidade e criação. Para Benjamin, porém, somente se pode ser fiel à língua pura, na medida em que ela nunca se apresenta, por si mesma, em uma língua qualquer, mas se manifesta a partir de uma certa relação harmoniosa e de um vínculo de afinidade (mas não de semelhança, Benjamin insiste nesse aspecto) de todas as línguas umas em relação às outras.

O messianismo dessa tarefa profunda e essencial consiste em respeitar o teleologismo (que é também um teologismo, vinculado a "uma rememoração de Deus [aufein Gedenken Gottes]") (BENJAMIN, 2008: 67) como lógica da tradução na obra de Benjamin. A finalidade sem fim, nunca perfeitamente bem-sucedida, da verdadeira tradução é a de nunca esquecer a tarefa fundamental, que seria cuidar para que a língua de origem seja lembrada, salvaguardada, em todo ato de traduçáo quase impossível do essencial, como evolução das relaçôes entre as línguas. "Redimir na própria a pura língua, exilada na estrangeira, liberar a língua do cativeiro da obra por meio da recriação essa é a tarefa do tradutor [Jene reine Sprache, die in fremde gebannt ist, in der eigenen zu erlösen, die im Werk gefangene in der Umdichtung zu befreien, ist die Aufgabe des Übersetzers]" (BENJAMIN, 2008: 79).

É por essa razão que Benjamin diz, no início de seu texto, que o conhecimento de uma obra de arte ou de uma forma artística não depende em nada 
do leitor. Não há tradução sem leitura, mas a própria leitura não traz nada de essencial à tarefa do tradutor, pois o que importa para traduzir bem se situa aquém e além do ato de ler: "Pois nenhum poema dirige-se ao leitor, nenhum quadro, ao espectador, nenhuma sinfonia, aos ouvintes" (BENJAMIN, 2008: 66). O essencial não é a relação entre o receptor e a obra de arte, mas o que a obra de arte já traz em si mesma, de maneira intrínseca, imanente, como potência, mas ainda por traduzir, a saber, a relação essencial entre as línguas, a relação das relaçôes, ou seja, a língua pura como teleologismo essencial de toda criação poética e, consequentemente, de todas as traduções possíveis, sejam elas verbais ou náo verbais (para lembrar a distinção de Roman Jakobson). No fundo, segundo o comentário de Derrida, somente se pode traduzir, na verdade, o tradutivel, aquilo que nunca pode ser o objeto de uma tradução, no sentido tradicional do termo, como ato de comunicação. O tradutível é o essencial de toda verdadeira tradução; aquilo que nunca chegará a ser traduzido no sentido corrente (pois isso corresponde ao traduzivel), e, no entanto, é aquilo que é preciso tentar traduzir, com o risco de falhar desde o início, desde a primeira palavra que se tenta traduzir, por exemplo, em um poema em prosa de Baudelaire. ${ }^{4}$ No que se refere a Derrida em seus textos sobre tradução, pode-se dizer que, também segundo Benjamin, somente se traduz, na verdade, o que náo é traduzível de maneira simples, o que ele chama de núcleo (der Kern) ou de intocável (unberührbar).

O núcleo essencial (dieser wesenhafte Kern) da verdadeira tradução designa o que se chega a traduzir, mas que, por sua essência mesma, não poderá ser retraduzido. É nisso que reside o limite de toda tradução, a impossibilidade de retradução do que, graças a um grande esforço, se conseguiu traduzir:

Em termos mais precisos, pode-se definir esse núcleo essencial como aquilo que numa tradução não pode ser retraduzido. Subtraia-se da tradução o que se puder em termos de informação e tente-se traduzi-lo; ainda assim, restará intocável no texto aquilo a que se dirigia o trabalho do verdadeiro tradutor. Não é traduzível como a palavra poética do original, pois a relação do conteúdo com a língua é completamente diversa no original e na tradução (BENJAMIN, 2008: 73).

Para Benjamin, o valor de uma tradução permanece ambíguo. Por um lado, o original parece nada dever às traduçôes, já que estas lhe são sempre secundárias. Mas, por outro lado, a tradução tem um grande valor, uma impor-

\footnotetext{
${ }^{4}$ Para essa distinção entre o tradutível e o traduzível, cf. DERRIDA, Jacques. "Des tours de Babel". Texto escrito em 1980, primeira versão publicada em 1985 em Difference in translation. Ed. bilíngue. Ed. Joseph Graham. Ithaca; London: Cornell University Press, 1985: 209-248, e em L'Art des confins. Mélanges offerts à Maurice de Gandillac. Org. Annie Cazenave; Jean-François Lyotard. Paris: PUF, 1985: 209-237; retomado em Psyché. Inventions de l'autre. Paris: Galilée, 1987: $203-$ 235. (Col. La philosophie en effet); e finalmente republicado em Psyché. Inventions de l'autre I. Ed. renovada, revista e ampliada. Paris, Galilée: 1998: 203-235 (Col. La philosophie en effet).
} 
tância totalmente especial, vinculada à sobrevivência (Überleben) do texto. Eis a frase que resume a ambiguidade do valor de uma tradução: "A obra da tradução tem um cunho inferior ao de ambas; entretanto, imprime marcas não menos profundas na história" (BENJAMIN, 2008: 76). Desse modo, a tradução constitui um capítulo ao mesmo tempo secundário, menor, e profundo, essencial, até mesmo primário na história da evolução das línguas em direção à sua relação harmoniosa no seio de uma língua pura:

Entretanto, se elas evoluírem de tal forma até o fim messiânico de sua história, será à traduçấo - que se inflama na eterna continuaçấo da vida das obras e no infinito reviver das línguas - que tocará questionar aquela sacra evolução das línguas: A que distância está da revelação aquilo que elas ocultam? Em que medida pode, sabendo-se dessa distância, o elemento oculto tornar-se presente [wie gegenwärtig es im Wissen um diese Entfernung werden mag]? (BENJAMIN, 2008: 72-73).

Antes de abordar o texto de Benjamin, "A tarefa do tradutor", de maneira direta em seu ensaio "Torres de Babel”, Derrida retoma o mito de Babel a partir de duas traduçôes francesas, uma mais clássica, aquela de Louis Segond (1910), e a outra mais recente e que se quer literal, aquela de André Chouraqui, traduzida palavra por palavra, como Cícero aconselhava a náo fazer. O mito de Babel (palavra que designa o nome de Deus Pai, e a "confusão") é, pois, uma espécie de entrada para a releitura que será proposta do texto de Benjamin. Toda a questão, segundo a citação de duas traduçóes do texto em hebreu, é a história de um povo que quis, através da construção da torre, fazer um nome e dessa maneira se reunir, impedindo toda dispersão. Nominação e reunião constituem dois valores nesse caso complementares: fazer um nome é uma maneira de evitar a dispersão. Porém, Deus Pai sente a construção de uma torre e a afirmação de um nome como um desafio à sua autoridade, o desejo de um nome e de uma torre com contornos universais. Assim, ele lhes impóe seu nome, o nome do pai, o nome próprio de Babel, que é também um nome comum que significa "confusão" - tal como "Pierre", em francês, assinala ao mesmo tempo o nome próprio e o nome comum: "Pedro" e "pedra". Lá, onde os construtores da torre teriam desejado a reuniáo, Deus lhes impôs a dispersão, ou antes, dirá Derrida, a disseminação como desconstrução. É o próprio Deus que desconstrói o que os homens teriam desejado construir, forçados pela divisão e pela impossibilidade de uma transparência pura. Doravante, a tradução se impóe como necessidade, como imperativo (é preciso traduzir, pois as línguas não são substituíveis, nem convertíveis umas pelas outras) e como impossibilidade (na falta de uma língua única, verdadeira, universal que reunisse todas as línguas; a tradução, no fundo, nunca terminará, permanecendo para sempre um processo interminável). Citemos o texto "Torres de Babel”, após a queda de Babel, ou após a queda simplesmente: 
Não se pode então falar de um ciúme de Deus? Por ressentimento contra esse nome e esse lábio [ou essa língua, tradução clássica da palavra hebraica por Louis Segond, E. N.] únicos dos homens, ele impóe seu nome, seu nome de pai; e com essa imposiçáo violenta enceta a desconstrução da torre como da língua universal e dispersa a filiação genealógica. Ele rompe a linhagem. Impóe e interdita ao mesmo tempo a tradução. [...] A tradução torna-se então necessária e impossível como o efeito de uma luta pela apropriação do nome, necessária e interdita no intervalo entre dois nomes absolutamente próprios. E o nome próprio de Deus já se divide o bastante na língua, para significar também, confusamente, "confusão". E a guerra que ele declara faz inicialmente furor no interior de seu nome: dividido, bífido, ambivalente, polissêmico: Deus desconstrói. Ele mesmo. "And he war", lemos em Finnegans Wake, e poderíamos seguir toda essa história na direção de Shem e de Shaun. ${ }^{5}$

Deus é uma figura ao mesmo tempo central e deslocada nesse trecho: "dividido, bífido, ambivalente, polissêmico", pois não é mais um deus todo-poderoso, construtor, aquele do fiat original que comparece em cena, mas um Deus humano, demasiado humano, vingador, que desconstrói o que suas criaturas fizeram, a própria torre, e lhes dará um nome, Babel, que será doravante traduzido "por confusão". ${ }^{6}$

O princípio divino é o princípio da divisão, da desconstrução, da disseminação e, pois, antes de tudo, da tradução como transferência (Übersetzung e Übertragung, Übersetzung como Übertragung): uma relação de amor e de ódio, de proximidade e de distância, em resumo, de reinvenção da genealogia. "And he war" (cf. DERRIDA, 1986: 16), expressão emprestada de Joyce, nomeia a duplicidade das línguas em uma mesma frase (o inglês e o alemão) como o desafio de traduzir o que é dificilmente traduzível: a multiplicidade das línguas, pois, como recorda Derrida, as teorias da tradução somente pensam na relação entre duas línguas, ou seja, em casais de línguas e não na multiplicidade em um mesmo ato de tradução. A guerra dos sentidos assinala a interdição da transparência entre as línguas, e mesmo a impossibilidade essencial de uma língua universal, "pura”, "verdadeira”.

O ensaio de Derrida, "Torres de Babel”, é uma interpretação que se assume como tal, seja porque ele seleciona o que lhe interessa no texto de Benjamin - tal qual ele fará anos mais tarde com o sonho "francês" de Benjamin, que ele resume em Fichus, como ele o diz de maneira explícita em um parêntese: “(é minha própria seleção interpretativa)” (DERRIDA, 2002a: 26), seja porque ele dá um sentido particular, imprimindo uma certa dire-

\footnotetext{
${ }^{5} \mathrm{Na}$ tradução para o português do ensaio “Torres de Babel”, citado por Evando Nascimento, optou-se pela edição brasileira, eventualmente com pequenas modificaçóes. Neste caso, o livro Torres de Babel. Trad. Junia Barreto. Belo Horizonte: UFMG, 2002: 18-9. [N. do T.] Grifos de Jacques Derrida.

${ }^{6}$ Um Deus comparável à divindade do Timeu, de Platão, do qual fala Derrida em "Avances", prefácio do livro de Serge Margel, Le Tombeau du dieu artisan. Paris: Minuit, 1995: 11-43.
} 
ção interpretativa ao texto benjaminiano, e esse é o ponto mais rico e mais delicado, o mais arriscado, sem o qual não há leitura. Derrida diz isso explicitamente em ao menos duas passagens de "Torres de Babel": "Pelo menos, tal é a minha interpretação - minha tradução, minha 'tarefa do tradutor"” (DERRIDA, 2002b: 18-19); e mais adiante: "Benjamin não conduz as coisas no sentido em que eu mesmo as traduzo, lendo-o sempre já na tradução" (DERRIDA, 2002b: 56. Grifos meus).

Estamos diante de uma tradução-interpretação vinculada, perfeitamente, ao fato de que se trata de um autor estrangeiro (Benjamin), mas um autor estrangeiro que Derrida lê ao mesmo tempo na tradução francesa e no original alemão (pois as citaçóes dos termos em alemão comparecem em sua obra ao lado de citações traduzidas). E esses atos de leitura-interpretação-tradução nada têm de um comentário imanente que permaneceria fechado no sistema interno do original. Pelo contrário, é a força performativa que relaciona o texto ao contexto, o texto-interpretado de Benjamin ao contexto filosófico, político, literário, religioso etc., do texto-interpretação de Derrida, aberto, ele próprio, a novas interpretações. A expressão "lendo-o sempre já na tradução" compreende todas as significações enunciadas: a partir de uma tradução preexistente e como forma de retradução interpretativa.

Nesses gestos de interpretação que partem de uma certa literalidade (ou proximidade) do texto do outro, portanto, de uma certa filologia, há também, desde o início, o gesto coextensivo de interpretação como reinvenção do texto do outro. Daí o valor de performance, pois o valor é, segundo o Derrida de "Assinatura Acontecimento Contexto", antes de tudo uma força que se efetua sobre o texto do outro, sobre seus "fios" (sua "malha": seu "tecido", ou seja, seu texto). E, no segundo gesto de interpretação tradutora, é a assinatura de Derrida que conta, uma assinatura que, decerto, não existiria sem "seus" outros (Benjamin, Heidegger, Nietzsche, Levinas, entre tantos outros), mas que afirma sua força no movimento de distanciamento, de partida do ponto de origem (como disse, de maneira explícita, Donner le temps (DERRIDA, 1991: 130)). Um nome próprio, uma assinatura, é alguma coisa que se encontra à beira do texto, em suas bordas, e que se faz sempre como contra-assinatura, assinatura após a assinatura do outro, nas costas do outro, ali onde se esperava uma simples filologia. $\mathrm{E}$ as relações entre filologia e interpretação, entre comentário e invenção, entre literalidade e resto constituem um dos maiores temas-formas do livro Béliers. Nele se encontra uma espécie de resumo no momento em que Derrida se prepara para ler-traduzir, ler traduzindo, o verso de Paul Celan, "Die Welt ist fort, ich muss dich tragen":

Não desenvolverei aqui, não teria tempo para isso, e tentei fazê-lo em outro lugar, protocolos de natureza teórica ou metodológica. Nada direi, diretamente, 
da fronteira intransponível, mas sempre abusivamente transposta, entre, por um lado, indispensáveis aproximaçóes formais, mas também temáticas, politemáticas, atentas, como deve ser toda hermenêutica, às dobras explícitas e implícitas do sentido, aos equívocos, às sobredeterminações, à retórica, ao querer-dizer intencional do autor, a todos os recursos idiomáticos do poeta e da língua etc., e, por outro lado, uma leitura-escritura disseminal que, se esforçando para levar tudo isso em conta, e para dar conta, respeitando a necessidade, se dirige também em direção a um resto ou a um excedente irredutível. O excesso desse resto se subtrai a toda reunião em uma hermenêutica. Essa hermenêutica, ele a torna necessária, tornando-a também possível, como torna aqui possível, entre outras coisas, o rastro da obra poética, seu abandono ou sua sobrevivência, além de tal signatário e de todo leitor determinado. Sem o resto, não haveria o Anspruch, a injunção, o chamado, nem a provocaçáo que canta ou faz cantar em todo poema, no que se poderia nomear, com Celan, segundo o título ou o incipit de um outro poema de Atemwende, Singbarer Rest(DERRIDA, 2003: 47-48. Grifos de Jacques Derrida).

Mesmo se parece muito próximo de Benjamin, o ensaio "Torres de Babel”, de Derrida, póe em causa alguns pontos fundamentais da reflexão benjaminiana sobre a tradução. E ele o faz de maneira performativa, assumindo a interpretação como ato de invenção ou de criação, tal qual - até um certo ponto Benjamin também o pensava para o trabalho do tradutor. Segundo Benjamin, esse trabalho é antes de tudo uma tarefa, "Aufgabe", palavra que contém em si, como já sublinhamos, alguma coisa de doloroso, um dever (mas também uma renúncia), e que permite, assim, a Derrida traduzi-la em francês por "dívida". O trabalho do "verdadeiro" criador pode ser livre, soberano, como aquele do escritor do original, mas o trabalho do tradutor permanece uma tarefa, pois ele é secundário em relação ao original. Mesmo se este se endivida a seu modo, e desde já diante das traduções futuras, para sobre-viver, sua existência é primária, livre; todavia, não se pode imaginar uma tradução sem original. Essa hierarquia entre original e tradução que, no fundo, permanece bastante tradicional, não será jamais colocada em questão por Benjamin (BENJAMIN, 2008: 68).

Para Derrida, porém, trata-se de uma perspectiva totalmente diferente. Primeiro, como vimos assinalando, o original está desde o início bastante endividado diante de suas traduçóes ainda e sempre futuras - como um dom. Os originais, no sentido forte, convocam as traduções, isso faz parte de sua estrutura, mesmo se estas demoram a se produzir. Sua "sobrevivência" (Überleben) e a "continuação dessa vida" (Fortleben) estão bastante ligadas aos atos de tradução, à disponibilidade dos tradutores e dos editores estrangeiros. Por outro lado, para Derrida, a tradução é também uma poderosa metáfora do ato de invenção como um todo. E é mais do que uma metáfora (ele utiliza o brilhante neologismo da "ametáfora" (DERRIDA, 2002b: 51)), pois ela é feita de dobras e redobras; o modo como ele trabalha a metáfora da tradução póe fundamentalmente em causa a relação entre sentido literal e sentido figurado 
que forma a base de toda teoria da metáfora desde Aristóteles. Todo ato de linguagem começa por uma via que é um desvio (Umweg), ou seja, pela repetiçáo ou pela impossibilidade de partir de um simples ponto de origem e de retornar a ele. Eis o tipo de enunciado que se encontra ao longo da imensa obra de Derrida: a prótese é originária, tudo começa pela repetição e pela duplicação (questão fundamental de textos pertencentes a épocas bem distantes, como "Freud e a cena da escritura", dos anos 1960, e Le Monolinguisme de l'autre ou La prothèse d'origine, dos anos 1990). É por isso que nunca há, para Derrida, um sentido literal a partir do qual se poderia derivar um sentido figurado. Não há original. Não há original que já não se apresente como secundário, derivado, portanto não originário - ou seja, traduzido. (É também a temática do "Pierre Ménard, autor do Quixote", de Borges).

Todo texto começa pela retomada de um ou de vários textos já existentes. Não há ato de criação absoluto, pois, como é dito em "Torres de Babel”, o autor está desde sempre morto; logo que a maquinaria da linguagem (ou da escritura) se póe a trabalhar, a morte antecipada de seu autor tem lugar. $\mathrm{Na}$ verdade, nunca devemos esquecer que, segundo Derrida, o "presumido criador do original" está, "ele também, endividado, taxado, obrigado por um outro texto, a priori tradutor" (DERRIDA, 2002b: 63). A demiurgia romântica, que Benjamin subscreverá de mais de uma maneira, se encontra profundamente desestabilizada por essa impossibilidade de pensar a origem sem repetição.

Daí a ironia de Derrida a propósito da expressão de Roman Jakobson "tradução propriamente dita"; as outras, impróprias, seriam a rewording (reformulação) e a transmutation. Não há tradução propriamente falando... Todo ato de língua ou de linguagem (Sprache) é uma tradução de outros atos prévios de linguagem. A tradução propriamente dita, ou no sentido próprio do termo (entre duas línguas), apenas repete o que todo discurso faz, a saber, traduzir, desde sempre, desde o Verbo original, se houve um, um só, o Um... O discurso começa pela repetição, a origem da linguagem é um ato que implica um contrato de repetição e de tradução, uma letra ou uma dívida para com o outro, uma dívida que, por definiçấo, é impossível de reembolsar e que, por esse motivo, está anulada. E é igualmente por essa razão que é preciso falar. É isso que é preciso (em Derrida, o é preciso [il faut] significa etimologicamente a falta e o dever, a dívida), pois esse contrato nunca será preenchido, terminado, definido por um ato definitivo de linguagem. Por um lado e por outro, há apenas traduçóes, mais ou menos fiéis, mais ou menos belas e infiéis. É preciso ser absolutamente fiel à palavra do outro, à palavra que se retoma do outro e à palavra que lhe prometemos dar, por um ato de fé jurada. Esse constitui o tema maior do filologismo em Nietzsche e em Derrida, por exemplo, no texto já citado, Béliers. É preciso ler os textos minuciosamente tal qual 
o faz Derrida em relação a "A tarefa do tradutor", analisando seus motivos e proposiçóes, seus axiomas e filosofemas. Mas é preciso também, por meio de um outro gesto, ser capaz de interpretá-lo no sentido nietzschiano (penso, por exemplo, na Genealogia da moral), não para aí reencontrar um sentido profundo, um significado fundamental, mas para deslocar os sentidos, para se distanciar e se reencontrar em outras páginas e paragens. Sem essa volta [tour], sem esse desvio [détour] e sem esse volteio [tournure de phrase], não há leitura, mas uma simples cópia que nada diz de novo, que repete somente a palavra do outro, por excesso de fidelidade e sem nenhum gesto radical de tradução. Nessa ampla perspectiva, um pensamento da tradução permanecerá sempre decisivo e fundamental para a disseminação e para a desconstrução, para as desconstruçôes disseminantes. Pensar, na obra de Derrida, é pensar essa relação não originária, derivada, disseminativa, "tradutora", com a palavra que vem sempre do outro, ou melhor, do totalmente outro. Relação, pois, com essa chegança inaudita que condensa toda a questáo da hospitalidade do último Derrida.

É sempre importante lembrar que a filologia no sentido nietzschiano já é necessariamente inventiva, o amor da palavra ou do discurso (logos) implicando a possibilidade de reinvenção interpretativa, ou seja, criadora, sem repetição anódina. Um tal valor filológico exige um novo conceito de philía.

Tudo o que está em jogo em Politiques de l'amitié se concentra no sentido da distinção entre dois tipos de philía, mas sem oposição simples. $\mathrm{O}$ primeiro, que remonta às fontes gregas da palavra, guarda uma relação com a oikeiótes que, segundo Jean-Claude Fraisse, "assume, pois, todas as significaçóes originais do termo phílos, acentuando sem dúvida mais do que ele a relação com a pessoalidade e a interioridade" (FRAISSE, apud DERRIDA, 1994: 178, nota 3). O segundo sentido de philía é o que Derrida tenta refletir, o "de uma amizade sem lar, de uma philía sem oikeiótes. No limite, sem presença, sem semelhança, sem afinidade, sem analogia" (FRAISSE, apud DERRIDA, 1994: 178, nota 3). É exatamente isso que Derrida pede àquele que procura ler uma certa semelhança e uma certa relaçáo de proximidade entre todos aqueles que alguns chamam de os pensadores ou os "filósofos da diferença" (o próprio Derrida, Foucault, Deleuze, Lyotard e alguns outros): mais além de toda analogia, o que náo permite reuni-los sob uma mesma bandeira, seja ela a mais decisiva, pois isso significaria, desde o início, perder o que esses pensadores têm de mais importante - sua própria singularidade: "seriam necessários outros protocolos de leitura e de escritura para deixar respirar os quase-idiomas, as diferenças e os desacordos. Tanto mais que a referida configuração se reúne visivelmente, como foi observado com frequência, o que náo significa que isso seja falso, sob o signo da diferença, e de 
uma diferença, como de um simulacro, não dialetizável' (DERRIDA, 1992: 257. Grifos de Jacques Derrida). Essa diferença guarda toda a força de uma distância, que não permite reuniăo em uma configuração epocal, "eis o que marca, ao menos em potência, reservas ou distâncias difíceis de integrar em uma configuração" (DERRIDA, 1992: 256-257). Uma philía, que não representa uma afiliação sem mediação e menos ainda uma homogeneidade irredutível, é o que exige um pensamento da diferença, se existe um. Ser amigo náo quer dizer forçosamente estar próximo, nem ser irmão ou colega; mas é talvez com uma amizade na distância e na diferença que sonha Derrida. Sonho táo impossível quanto aquele de pensar que o mais estrangeiro pode às vezes ser o mais amistoso, o mais caloroso e apto a ser acolhido em sua casa. É nesse sentido que um conceito não homogeneizante e não fraternal, um náo conceito, pois, de amizade, pode se revelar o mais incondicionalmente hospitaleiro, desconstrutor.

É o que Derrida nos dá a pensar, após um dos filósofos de que ele esteve muito próximo em toda a sua vida, mas, na qualidade de "amigo", também frequentemente o mais distante - Heidegger: "Qual seria a força política de um pensamento ou de uma experiência do phileîn que não respeitasse mais essa lei de reciprocidade e se submetesse à dessemelhança, à heterogeneidade, à dissimetria, à desproporção, à incomensurabilidade, à não troca, ao excesso de toda medida e, portanto, de toda simetria?" (DERRIDA, 1994: 372).

Nesse contexto, em que se trata uma vez mais de colocar em questáo o valor heideggeriano de "reunião" (Versammlung), é uma certa política da amizade latina, enquanto tradução da philía grega, que se encontra deslocada em relação ao seu quadro filosófico tradicional. Para Derrida, a amizade é também o tema do estrangeiro enquanto estrangeiro; e são, pois, também novas políticas da interpretação tradutora que é preciso desenvolver. Em nome de uma verdadeira democracia, sempre ainda por vir e que resta a pensar.

Tradução de Davi Andrade Pimentel (UFF)

Referências bibliográficas

BENJAMIN, Walter. "A tarefa-renúncia do tradutor". Trad. Susana Kampff Lages. In: BRANCO, Lucia Castello (Org.). A tarefa do tradutor, de Walter Benjamin: quatro traduçóes para o português. Belo Horizonte: UFMG, 2008.

. "Die Aufgabe des Übersetzers". In:TIEDEMANN, Rolf; SCHWEPPENHÄUSER, Hermann (Org.). Gesammelte Schriften. v. 4. Frankfurt am Main: Suhrkamp Verlag, 1991. 
DERRIDA, Jacques. Béliers. Le dialogue ininterrompu: entre deux infinis, le poème. Paris: Galilée, 2003.

. “La langue de l'étranger", Le Monde Diplomatique, jan. 2002a: 26.

. Torres de Babel. Trad. de Junia Barreto. Belo Horizonte: UFMG, 2002 b.

. Politiques de l'amitié suivi de L'oreille de Heidegger. Paris: Galilée, 1994.

. "Nous Autres Grecs". In : CASSIN, Barbara (Org.). Nos Grecs et leurs

modernes. Les stratégies contemporaines d'appropriation de l'Antiquité. Paris: Seuil, 1992.

. Donner le temps. v. 1. La fausse monnaie. Paris: Galilée, 1991.

. Ulysse gramophone. Deux mots pour Joyce. Paris: Galilée, 1986.

Evando Nascimento é professor universitário, pesquisador e escritor. Seu trabalho se desenvolve em torno das áreas de Filosofia, Literatura e Artes Plásticas. Completou sua formação em Paris, onde foi aluno de Jacques Derrida (na École des Hautes Études en Sciences Sociales) e de Sarah Kofman (na Sorbonne). Em 2007, realizou um pósdoutorado em Filosofia na Universidade Livre de Berlim. Tem diversos livros publicados, como autor ou organizador: Derrida e a literatura (2. ed., EdUFF) e Pensar a desconstrução (Ed. Estação Liberdade), entre outros. Coordena atualmente a Coleção Contemporânea, pela Civilização Brasileira. Publicou, igualmente, os livros de ficção Retrato desnatural (2008), Cantos do mundo (2011), ambos pela Record, e Cantos profanos (2014), pela Globo Livros.

Recebido em: 10/08/2014. Aprovado em: 01/09/2014. 